\title{
An International Perspective on Corporate Social Responsibility and its Role in Community Development
}

\author{
Shanmuganathan S
}

\begin{abstract}
Corporate social responsibility (CSR) refers to strategies corporations or firms conduct their business in a way that is ethical, society friendly and beneficial to community in terms of development. This article analyses the meaning of CSR based on some theories available in literature. It is argued that three theories namely utilitarian, managerial and relational theories of CSR supported by works of other scholars in the area could be used to suggest that CSR becomes an international concern due to globalized nature of business that knows no border. CSR is evolving in its meaning and practice. The article then discusses the role of CSR in community development because the very logic of CSR is towards seeing its impact in community socially, environmentally and economically. Competencies required by CSR managers are also analysed in order to have a better understanding of the practical aspects of CSR. Finally, conclusions and implications for future research are discussed.
\end{abstract}

Keywords : Corporate social responsibility, community development, competencies of CSR managers, multinational corporations, corporate-society relations.

\section{INTRODUCTION}

The issue of corporate social responsibility (CSR) has been debated since the 1950s. Latest Analyses by Secchi (2007) and Lee (2008) reported that the definition of CSR has been changing in meaning and practice. The classical view of CSR was narrowly limited to philanthropy and then shifted to the emphasis on business-society relations particularly referring to the contribution that a corporation or firm provided for solving social problems. In the early twentieth century, social performance was tied up with market performance. The pioneer of this view, Oliver Sheldon (1923, cited in Bichat, 2003), however, encouraged management to take the initiative in raising both ethical standards and justice in society through the ethic of economizing, i.e. economize the use of resources under the name of efficient resource mobilization and usage. By doing so, business creates wealth in society and provides better standards of living. The present-day CSR (also called corporate responsibility, corporate citizenship, responsible business and corporate social opportunity) is a concept whereby business organizations consider the interest of society by taking responsibility for the impact of their activities on customers, suppliers, employees, shareholders, communities and other stakeholders as well as their environment. This obligation shows that the organizations have to comply with legislation and voluntarily take initiatives to improve the well-being of their employees and their families as well as for the local community and society at large. CSR simply refers to strategies corporations or firms conduct their business in a way that is ethical and society friendly. CSR can involve a range of activities such as working in partnership with local communities, socially sensitive investment, developing relationships with employees, customers and their families, and involving in activities for environmental conservation and sustainability. This article aims to analyse three theories of CSR namely utilitarian, managerial and relational in terms of their meaning and practical emphases. These groups of theories are chosen because they are interdisciplinary in nature covering aspects of economic system, the managerial aspects of the corporation and the beneficiaries. The paper then highlights the role of CSR in community development based on an international perspective due to the heterogeneity of CSR in its understanding and practices in various countries of the world. The organization of the article is as follows: First, theories of CSR are analysed in order to look at their emphases of meaning, perspective, and approaches. Second, the roles of CSR are highlighted specifically in community development because the very logic of CSR is towards seeing its impact in community socially, environmentally and economically. Third, competencies required by CSR managers are discussed in order to have a better understanding of the practical aspects of CSR. Finally, Conclusions and implications for future research are drawn. 


\section{THEORIES OF CSR}

Since there is a great heterogeneity of theories and approaches of CSR, discussion in this article is based on a comprehensive analysis by Secchi (2007) and it is compared with an analysis by Garriga and Mele (2004). Secchi has come up with a group of theories based on a criterion what role the theories confer to the corporation and society. The theories are as follows: 1) The utilitarian theory, 2) The managerial theory, and 3) The relational theory (see Table 1). On the other hand, Garriga and Mele's (2004) analysis maps CSR into four types of territories. They are: 1) Instrumental theories, 2) Political theories, 3) Integrative theories, and 4) Ethical theories. Table 2 describes the theories and the relevant approaches. There is no doubt that some similarities do exist in both conceptualizations of CSR and the discussion will be based on emphases and approaches.

\section{Utilitarian Theories}

In the utilitarian theories the corporation serves as a part of the economic system in which the

Function is mechanical i.e. traditionally known as in profit maximization. CSR ideas emerged after a realization that there is a need for an economics of responsibility, embedded in the business ethics of a corporation. Hence, the old idea of laissez faire business gives way to determinism, individualism to public control, and personal responsibility to social responsibility. Utilitarian could also be taken synonymously with instrumental theories (Garriga and Mele, 2004; Jensen, 2002) in which the corporation is seen as only an instrument for wealth creation, and its social activities are only a means to achieve economic results. Instrumental theories were also based on the basic idea about investment in a local community in which Friedman (1970) strongly stated earlier that the investment will be in long run provide resources and amenities for the livelihoods of the people in the community.

The utilitarian theories are related to strategies for competitive advantages. The proponents of These theories are, for instance, Porter and Cramer (2002) and Litz (1996) who viewed the theories as bases for formulating strategies in the dynamic usage of natural resources of the corporation for competitive advantages. The strategies also include altruistic activities that are socially recognized as instruments for marketing. Secchi (2007) further divides the utilitarian group of theories into two, namely, the social costs of the corporation and the idea of functionalism. The social cost theory has a basis for CSR in which the socio-economic system in the community is said to be influenced by the corporate non-economic forces. It is also called instrumental theory (Garriga and Mele, 2004) because it is understood that CSR as a mere means to the end, which leads to the fact that the social power of the corporation is materialized specifically in its political relationship with society. The utilitarian theory, therefore, suggests that the corporation needs to accept social duties and rights to participate in social co-operation. Within it, the functionalist theory, specifically advocates that the corporation is seen as a part of the economic system, which one of the goals is profit making. The firm is viewed as an investment, and investment should be profitable to the investors and stakeholders. Putting it from the internal point of view of the firm, CSR was coined as a defence tactic of the industrial system against external attacks because there needs a balance between profit making and social objectives for the economic system's equilibrium.

\section{Managerial Theory}

Secchi's (2007) analysis further stresses the logic of managerial theory that emphasizes corporate management in which CSR are approached by the corporation internally. This makes the difference between utilitarian and managerial perspective of CSR. This suggests that everything external to the corporation is taken into account for organizational decision making. Managerial theories have been divided into three sub-groups: 1) Corporate social performance (CSP); 2) Social accountability, auditing and reporting (SAAR), and 3) Social responsibility for multinationals. CSP aims to measure the contribution the social variable makes to economic performance. Thus, the problem is that of managing the firm considering social and economic factors together. It is based on the assumption that business depends on society for its growth and sustainability. CSP of a corporation is further sub-divided into five dimensions in order to keep detailed information about its existence in the corporate chains: 1) Centrality measures the way CSR is compatible with mission of the core goals; 2) specificity gauges the advantages CSR brings to the corporation; 3) pro-activity that measures the degree of reaction to external demands; 4) voluntarism that accounts for the discretion the firm in implementing CSR; and 5) visibility refers to the way the responsible behaviour is perceived by community of stakeholders. As conclusion, the managerial theory generates interests in the sense that CSR considers socio-economic variables to measure firms' socio-economic performance, as well as to link social responsibility ideology to business strategy. Secchi (2005) further elaborates that SAAR are strictly related to social performance contributions through accounting, auditing and reporting procedures. SAAR means 
a firm accounts for its action. By doing so, firms are controlled and regulated in their actions towards performing their core business while responsible to the relevant community.

The three activities are separate managerial activities but they are interrelated to each other. All these contribute to the socially responsible behaviour of a firm, which finally measures the corporations' activities that have social impact. Firms are involved in SAAR activities for communication needs, to have better stakeholder involvement and for discloser concerns

CSR for multinationals (MNCs) grows as a result of global competitions and challenges they Faced. This aspect of managerial theory comes into being as a result of the responsibility the managers have to shoulder by defining useful tools about the CSR for the MNCs to survive in foreign countries. Donaldson (1989, cited in Secchi, 2007: 359) refers to the MNCs as 'moral agents', analysed on the basis of the moral values when managers make decision in the firms, going beyond profit maximization. The logic of CSR for MNCs is also derived from the fact that when cultural clashes become relevant due to events such as protests, demonstrations, boycotts, strikes and other negative actions against the employers. The answer to these actions is the formulation of 'code of conduct' that should be adopted by MNCs. The success of this initiative, however, depends on client expectation and corporate reputation; the level of trust, acceptance, and cooperation shown by the stakeholders and community of workers. Managerial theories are also strongly related to political theories based on the conceptualization by Garriga and Mele (2004) (see Table 2) and supported by Wood and Lodgson (2002) as well as Detomasi (2008). They stress that social responsibilities of businesses arise from the amount of social power a corporation has and the corporation is understood as being like a citizen with certain involvement in the Community.

\section{Relational Theory}

Relational theory has a root from the complex firm-environment relationships. As the term

Implies, interrelations between the two are the focus of the analysis of CSR. As indicated in Table 1, relational theory is further divided into four sub-groups of theories: 1) business and society; 2) stakeholder approach; 3) corporate citizenship; and 4) social contract. Business and society is proposed to mean 'business in society' in which CSR emerges as a matter of interaction between the two entities. One of the measures of CSR is the development of economic values in a society. Another is a person's obligation to consider the effects of his decision and action on the whole social system.
Stated in the form of a general relationship, social responsibilities of businessmen need to reflect the amount of social power they have. Stakeholder approach has been developed as one of the strategies in improving the management of the firm. It is also said as a way to understand reality in order to manage the socially responsible behaviour of a firm. The stakeholder approach further considers a firm as an interconnected web of different interests where self-creation and community creation happen interdependently; and individuals behave altruistically. Based on Garriga and Mele's (2004) analysis, stakeholder approach is both within the integrative and ethical theories, where the former emphasizes the integration of social demands and the latter focuses on the right thing to achieve a good society. These are supported by the work of Mitchel, Agle and Wood (1997) where balances among the interests of the stakeholders are the emphases; and the work of Freeman and Phillips (2002) that considers fiduciary duties towards stakeholders of the firms, respectively. Corporate citizenship of the relational theory strongly depends on the type of community to which it is referred. It is a path that a corporation may take to behave responsibly.

\section{Role OF CSR IN COMMUNITY DEVELOPMENT}

First of all community is generally defined as a group of people sharing a common purpose, who are interdependent for the fulfilment of certain needs, who live in close proximity and interact on a regular basis. There are shared expectations for all members of the group and responsibility taken from those expectations. The group is respectful and considerate of the individuality of other persons within the community. In a community there is a sense of community which is defined as the feelings of cooperation, of commitment to the group welfare, of willingness to communicate openly, and of responsibility to and for others as well as to one's self. Most important there exists community leaders who are responsible for the success of any community event, depending on the needs of the community, and the individual's own feelings. The community leaders are individuals who strive to influence others to take responsibility for their actions, their achievements, and the community welfare.

Community development (CD) refers to initiatives undertaken by community with partnership with external organizations or corporation to empower individuals and groups of people by providing these groups with the skills they need to effect change in their own communities. These skills are often concentrated 
around making use of local resources and building political power through the formation of large social groups working for a common agenda. Community developers must understand both how to work with individuals and how to affect communities' positions within the context of larger social institutions.

$\mathrm{CD}$ is the process of developing active and sustainable communities based on social justice and mutual respect. It is about influencing power structures to remove the barriers that prevent people from participating in the issues that affect their lives. Community workers facilitate the participation of people in this process. They enable linkages to be made between communities and with the development of wider policies and programs. CD expresses values of fairness, equality, accountability, opportunity, choice, participation, mutuality, reciprocity and continuous learning. Educating, enabling and empowering are at the core of CD (Federation of Community Development Learning, 2009). CD is the combined processes, programs, strategies, and activities that make a community sustainable as compared to economic development which is the marketing of its potential for growth followed by local efforts to act on opportunities. The entire set of approaches to community development Practice may be considered a specialized form addressing, coordinating and building the social infrastructure at a location. CD may be defined as a process of challenging the undesirable and unacceptable disparity of conditions and infrastructure that negatively affect the quality of life in a place where people live and work. It functions best as process in locations where all strata of society and citizenry are engaged with sense of community solidarity (Community Glossary, 2009). The widely used meaning of $\mathrm{CD}$ is the one given by the United Nations (United Nations, 1971) in which CD is an organized effort of individuals in a community conducted in such a way to help solve community problems with a minimum help from external organizations. External organizations include government and non-government organizations, and corporations of various types and sizes such as small and medium enterprises (SMEs) and multinational corporations (MNCs). The implication of UN's definition of CD is, therefore, emphasizing creativity and self-reliance in the community for short and long term goals, but not to defy the CSR roles of the various types of business firms. In relation to the people, the definition of $\mathrm{CD}$ is essentially both an educational and organizational process. Another term closely related to $\mathrm{CD}$ is community work, which is about the active involvement of people in the issues that affect their lives and focuses on the relation between individuals and groups and the institutions which shape their everyday experience. It is a developmental process that is both a collective and individual experience. It is based on a commitment to equal partnership between all those involved to enable a sharing of skills, awareness, knowledge and experience in order to bring about change. It takes place in both neighborhoods and communities of interest, whenever people come together to identify what is relevant to them and act on issues of common concern. The key purpose is to work with communities experiencing disadvantage, to enable them to collectively identify needs and rights, clarify objectives and take action to meet these within a democratic framework which respects the needs and rights of others. Community work recognizes the need to celebrate diversity and appreciate differences among ethnic and social groups in the community.

\section{Common Roles OF CSR IN Community DEVELOPMENT}

From the above meaning of CSR, it is undeniable that CSR has implications on community and $\mathrm{CD}$ in many ways. Based on the report of Towers Perrin (2009) CSR is the third most important driver of employee engagement overall. For companies in the U.S. for instance, an organization's stature in the community is the second most important driver of employee engagement, and a company's reputation for social responsibility is also among the top 10 drivers. The role of CSR in CD used in this paper is any direct and indirect benefits received by the community as results of social commitment of corporations to the overall community and social system. The common roles of CSR in CD are discussed as follows:

1. To share the negative consequences as a result of industrialization. This is related to increasing conscience-focused marketplaces necessitating more ethical business processes.

\section{Closer ties between corporations and} community. Through CSR the existence of corporations in the social system is felt beyond a perception that corporation is a place just to get employment and producers of goods and services. By doing so, corporations and community would stay in peace and harmony. This becomes a social capital that is essential in community development.

3. Helping to get talents. Organizations with a reputation for CSR can take advantage of their status and strengthen their appeal as an attractive employer by making their commitment part of their value proposition for potential 
candidates. It is also found that when employees view their organization's commitment to socially responsible behaviour more favourably, they also tend to have more positive attitudes in other areas that correlate with better performance. They believe their organizations recognize and reward great customer service, act quickly to address and resolve customer concerns, and are led by people in senior management who act in the best interest of customers.

4. Role in transfer of technology (TOT). Closer ties help in TOT between MNCs that give concerns on CSR and communities in the host countries. MNC is a corporation that has its facilities and other assets in at least one country other than its home country. Such companies have offices and/or factories in different countries and usually have a centralized head office where they coordinate global management. Very large multinationals have budgets that exceed those of many small countries.

5. CSR helps to protect environment. Some of the world's largest companies have made a highly visible commitment to CSR, for example, with initiatives aimed at reducing their environmental footprint. These companies take the view that financial and environmental performance can work together to drive company growth and social reputation. This attitude can only serve to enhance the employment value proposition such as interest in "going green" gains traction (Towers Perrin, 2009). "We green the earth" slogan made by some MNCs in Malaysia who own large golf areas within the vicinity of residential areas is another CSR initiative seems to protect environment. Many non-profit organizations have been involved in learning and advocacy of environmental protection of CSR such as those reported by the United Nations. They are for example a) "Friends of the Earth" who highlights the environmental impact of some MNCs and campaign for stronger laws on environmental responsibility; b) "Green Peace mission" is another example of CSR initiative that gives benefit to society and community in preserving the latter's rights towards reaping healthy environment (Wikipedia, 2009). Green Peace is an independent global campaigning organization that acts to change attitudes and behaviour, to protect and conserve the environment and to promote peace by many ways, one of which is campaigning for sustainable agriculture and environment by encouraging socially and

Ecologically responsible farming practices.

6. CSR is for human right corporate sustainability. The United Nations have launched the "Global Compact" - an initiative to convince international companies to commit themselves to universal principles in relation to protection of human rights (UN Global Compact, 2009). Being the world's largest voluntary corporate responsibility initiative, the UN Global Compact is also seen a strategic policy for businesses that are committed to aligning their operations and strategies within the areas of human rights, labour, and environment. By doing so, business, as a primary agent driving globalization, can help ensure that markets, commerce, technology and finance advance in ways that benefit economies and societies everywhere. Never before have had the objectives of the international community and the business world been so aligned. Common goals, such as building markets, combating corruption, safeguarding the environment and ensuring social inclusion, have resulted in unprecedented partnerships and openness among business, government, civil society, Labour and the United Nations. This ever-increasing understanding is reflected in the growth of the Global Compact, which today stands as the largest corporate citizenship and sustainability Initiative in the world -- with over 4700 corporate participants and stakeholders from over 130 countries.

7. Interdependency between a corporation and community. The close link between a corporation and community is another aspect of CSR role in $\mathrm{CD}$ because in long run it creates sustainable development. This could be seen e.g. Shell Foundation involvement in the Flower Valley in South Africa and Marks and Spencer in Africa. The CSR projects give aids to local organization and impoverished communities. This certainly leads to sustainable community development

8. A CSR program can be seen as an aid to alleviate poverty. An example is a Malaysian reality program Bersamamu of TV3 which is sponsored by Syarikat Faiza Sendirian Berhad (SFSB), a local enterprise-cum-philanthropist who responds to government's appeal to help impoverished community to improve their livelihoods (SFSB, 2009). SFSB gets help from the local media company TV3 for publicity and audience support. This TV program is focused on the life reality of the poor, helpless and misfortune people in their survival. Every purchase of Faiza's Product, will entitle the buyer to make a donation to Tabung Bersamamu TV3 (a fund of the broadcasting agency). Through this collaboration it may trigger other corporations to help the nation in its effort to alleviate poverty and, hence, in developing communities. 
9. A CSR program helps in data gathering for other public organization function. For instance in the United States, Intel and IBM (examples of mega ICT firms) assisted under-staffed police departments with information gathering and processing by installing cameras with video processing abilities in areas where there are high rates of crimes. Intel has also conducted initiatives to educate local communities on how they can use technology to prevent crime or atleast to use it to detect who committed the crime. This is an example of technology companies implement CSR initiatives that both benefit community and support business objectives.

10. for corporate sustainability goals. In Europe and elsewhere outside the U.S., companies have been taking their social role seriously for years, often under the banner of corporate sustainability. The EU has developed a corporate sustainability framework, which identifies a progressive set of economic, social and environmental objectives that companies are encouraged to achieve. At Towers Perrin (2009), for instance, they have developed a methodology to assess the employee perspective on sustainable business practices (SBP). These practices represent a continuing commitment by a company to behave ethically and contribute to economic development while improving the quality of life of its workforce and family members, as well as the local community and society at large. Towers Perrin's SBP index specifically covers five areas: awareness and perceived importance among employees, employee sustainable behaviours, social and community performance, environmental performance, and ethical and legal performance.

\section{Skills NeEded by CSR Managers IN COMMUNity DeVElopment}

The success of CSR is determined by both internal and external factors. Internal factors are Economic considerations, culture of the firm including the CEO and employees, and ethical influences; while external factors are compliance with legal requirements and technological influences as well as national culture. Skills possessed by CSR managers are among the internal factors determining the success of CSR practices especially in helping community. Because CSR profession is so new, transferable skills and knowledge from other related specialization such as environmental management, business ethics, community development, and human resource development are valuable. Specific skills for CSR managers are very hard to clarify due to the diverse roles and range of disciplines involved. However, based on the UK's experience in CSR (Career Service, 2009), three main areas of skills are relevant. They are business skills, people skills and technical skills. Business skills include building insight, communication skills, decision making, commercial awareness, information technology, innovation, strategic awareness, leadership and problem solving. People skills cover adaptability and empathy, developing others in the community, influencing without power, integrity, political awareness, altruism, volunteerism, and adult learning. Finally, technical skills include technical expertise, understanding evaluation and impacts, stakeholder dialogue, human rights and understanding sustainability. Based on the above skills grouping, CSR managers should have six core competencies. They are understanding community and community development, building capacity, questioning business beyond profit making, stakeholder relations, strategic business and community partnership, and harnessing diversity. Hence, CSR managers have a wide range of career options such as in marketing, human resources, health and safety, environmental management, ethical investment, public relations, ethical science, community resource development and social research.

\section{CONCLUSION AND RESEARCH IMPLICATIONS}

It is concluded that CSR is about business, government and civil society collaboration with the bottom line is the achievement of win-win situation among the three entities. From the social point of view, CSR should benefit community because the latter has a very complex structure as it consists of individuals with various levels of control of resources physically and intangibly. The analysis on the theories allows the understanding of CSR that goes beyond its traditional meanings; therefore, CSR necessitates a multidisciplinary approach in its perspective and practice. Since the current meaning of CSR is complex, knowing the theories allows scholars to have a better understanding about corporation-society relations, in which theories and practices of CSR are influenced by numerous economic and non-economic as well as internal and external forces. Roles of CSR in CD refer to the ways the responsible behaviour is perceived by community of stakeholders and impacts are felt by them. The analysis shows that CSR proved to have many roles and the brought impacts to the community as follows: Closer ties and interdependencies between corporations and community, sharing the costs the society has to pay due to environmental degradation, Transfer of technology from international companies to developing countries, environmental protection measures that done together by corporation and the communities, poverty alleviation in the 
communities, human right advocacy, and helps in data gathering by ICT firms to facilitate public organization functions. For many corporation leaders, it is difficult to know where their responsibilities begin and end in relation to building infrastructure, creating economic opportunities, and access to core services such as health, education and poverty alleviation. Experience has made one thing certain those sustainable CSR solutions at Community, provincial and national levels are based on partnerships between government, civil society and business. It is also concluded that skills needed by CSR managers do vary due to the diverse disciplines involved and also the complexity of the roles and responsibilities of a CSR initiative. There are no specific qualifications required for this field. Because the field is new, transferable skills and knowledge from other related specializations such as environmental management, business ethics, transfer of technology, human resource management and community development, are valued.

\section{ACKNOWLEDGEMENT}

The research paper is funded by RUSA (Rashtriya Uchchatar Shiksha Abhiyan) Phase 2.0 Scheme by Ministry of Human Resource Development (MHRD), India.

\section{REFERENCES}

1. Barton, J. H. (2007). New Trends in Technology Transfer: Implications for National and International Policy, Issue Paper No. 18.Geneva: International centre for Trade and Sustainable Development (ICTSD).

2. Bichta, C. (2003). Corporate socially responsible industry (CSR) practices in the context of Greek. Social Responsibility and Environmental Management, 10, 12-24.

3. Career Service (2009). Corporate Social Responsibility and Ethical Careers. Available at: http://www.careers.ed.ac.uk, accessed on 12 Dec. 2008.

4. Davis, K. (1960). Can business afford to ignore corporate social responsibility? California Management Review, 2, 70-76.

5. Detomasi, D. A. (2008). The political roots of corporate social responsibility. Journal of Business Ethics, 82, 807-819.

6. Lee, M. P. (2008). Review of the theories of corporate social responsibility: Its evolutionary path and the road ahead.

7. International Journal of Management Reviews, 10, 1, 53-73.Litz, R. A (1996). A resource-based view of the socially responsible firm: Stakeholder interdependence, ethical awareness, and issue of responsiveness as strategic assets. Journal of Business Ethics, 15, 1355-1363.

8. Mitchell, R. K., Agle, B. R. and Wood, D. J. (1997). Towards a theory of stakeholder identification and salience: Defining the principle of who and what really counts, Academy of Management Review, 22(4),853-886.

9. Syarikat Faiza Sendirian Berhad (SFSB) (2009). Santapan Berkhasiat Sepanjang Hayat. (An Everlasting Nutritional Food). Available at: http://www.faizarice.com/index.htm, accessed on 12 Dec. 2008.

10. Secchi, D. (2005). The Italian experience in social reporting: An empirical analysis. Corporate Social Responsibility and Environmental Management, 13, 135-149.

11. Secchi, D. (2007). Utilitarian, managerial and relational theories of corporate social responsibility. International Journal of Management Reviews, 9, 4, 347-373

12. Swanson, D. L. (1995). Addressing a theoretical problem by reorienting the corporate social performance model. Academy of Management Review, 20(1), 43-64. 